\title{
The Impact of Electronic Word-of-Mouth Marketing on the Generation-Y's Intention to Buy Tourism Services
}

\section{Nuriye GÜREŞ ${ }^{D}{ }_{a}$ Seda ARSLAN ${ }^{D}{ }_{b}$ Cevher YÜKSEL ${ }^{\left(D_{c}\right.}$ Aylin VARIŞLI ${ }^{\text {id }}$ Duygu BABAT ${ }^{\text {De }}$ Menekşe GÜNDOĞDU ${ }^{i} f$}

a Iskenderun Technical University, Faculty of Aeronautics and Astronautics, İskenderun / Hatay, Turkey. nuriye.gures@iste.edu.tr

b Iskenderun Technical University, Faculty of Aeronautics and Astronautics, İskenderun / Hatay, Turkey. seda.arslan@iste.edu.tr

c Iskenderun Technical University, School of Foreign Languages, İskenderun / Hatay, Turkey. cevher.yuksel@iste.edu.tr

d Mustafa Kemal University, Antakya Vocational School, Turkey. aylinvarisli@mku.edu.tr

e Mustafa Kemal University, Antakya Vocational School, Turkey. dbabat@mku.edu.tr,

f Iskenderun Technical University, Faculty of Aeronautics and Astronautics, İskenderun / Hatay, Turkey. menekse.gundogdu@iste.edu.tr

\begin{tabular}{|c|c|}
\hline ARTICLE INFO & ABSTRACT \\
\hline $\begin{array}{l}\text { Keywords: } \\
\text { E-Wom } \\
\text { Generation-Y } \\
\text { Travel Services } \\
\text { Attitude }\end{array}$ & $\begin{array}{l}\text { Purpose - In recent years, social networks have been extensively used by both individuals and } \\
\text { companies. In particular, prior to the purchase of services, customers may be able to decide to } \\
\text { buy by considering the messages posted in social networks. Therefore, it is very important to } \\
\text { know how effective these messages on pre-purchase decisions of the customers. The purpose of } \\
\text { this study is to search the influence level of electronic word-of-mouth marketing (e-wom) on the } \\
\text { purchase decisions of the customers related to tourism services. }\end{array}$ \\
\hline $\begin{array}{l}\text { Received } 18 \text { March } 2019 \\
\text { Revised } 30 \text { April } 2019 \\
\text { Accepted } 25 \text { May } 2019\end{array}$ & $\begin{array}{l}\text { Design/methodology/approach -The survey was conducted in both face to face and on the } \\
\text { internet. A total of } 485 \text { people have been reached. T-test, ANOVA and regression methods were } \\
\text { used for the analysis of data. }\end{array}$ \\
\hline $\begin{array}{l}\text { Article Classification: } \\
\text { Research Article }\end{array}$ & $\begin{array}{l}\text { Findings - According to the analysis results, the trust in e-wom, the quality of e-wom and the } \\
\text { willingness of customers to obtain information have a positive impact on the intention to } \\
\text { purchase tourism services. }\end{array}$ \\
\hline & $\begin{array}{l}\text { Discussion - Businesses operating in the tourism sector should carefully review the feedback } \\
\text { made with E-WOM for their services and resolve the problems. Thus, by reducing negative } \\
\text { feedback in particular, customers ' intentions to purchase tourism services can be positively } \\
\text { affected. }\end{array}$ \\
\hline
\end{tabular}

\section{Introduction}

Intensive developments in information and communication technologies have paved the way for the emergence of intelligent technologies (Caragliu et al., 2011: 66; Wang et al., 2016: 309). The use of intelligent technologies that can be connected to the internet and that enable interactive use is now widely adopted by other individuals as well as young generations (Foroudi et al., 2018: 271). The tourism industry also often adopts technological innovations in the forefront (Gretzel, 2011: 757; Bhatiasevi and Yoopetch, 2015: 1; Yoo et al., 2017: 330). In particular, the development of Internet technologies and social media sites in parallel has led to the intensification of competition in the tourism industry and changes in the marketing of tourism services (No and Kim, 2015: 564; Hur et al., 2017: 170; Huang et al., 2017: 757). Nowadays, thanks to tourism and travel operators, internet technologies and social media sites, it is possible to offer transactions such as hotel reservations, airline tickets, car rentals to customers online (Yoo et al., 2017: 330).

Unlike physical products, tourism services are intangible, so production and consumption are simultaneous (Ye et al., 2014: 908). At the same time, the prices of tourism services are relatively high compared to other sectors (No and Kim, 2015: 564). Therefore, customers who intend to purchase tourism services can obtain information about accommodation, and leisure activities before purchasing the tourism service, especially through social media sites, from the comments of people who have experienced this service before. Thus, Önerilen Atıf/ Suggested Citation:

Güreş, N., et al, (2019). The Impact of Electronic Word-of-Mouth Marketing on the Generation-Y's Intention to Buy Tourism Services, Journal of Business Research-Turk, 11 (2), 905-916. 
N. Güreş - S. Arslan - C. Yüksel - A. Varışl1 - D. Babat - M. Gündoğdu 11/2 (2019) 905-916

tourists may get ideas about the service they will receive prior to their travels and reduce the risk (Fotis et al. 2012: 14; Amaro et al., 2016: 2). In addition to getting information about tourism services, customers use social media sites extensively because of their hedonic benefits (Chung and Buhalis, 2008: 75). Therefore, more people today use social media sites to get an idea of tourism services (Bilgihan et al., 2016: 287). However, at this point, the fact that the information contained in social media sites is not misleading and that quality information is included can be regarded as an important element (Alfina et al., 2014: 2519). For this reason, in this study, the effect of e-wom on customer service purchase was searched.

\section{Conceptual Background}

\section{Y-Generations}

Throughout the world, serious changes are taking place in certain periods and in certain areas (economic, social etc.). These changes bring about certain movements and these movements are called generations. There are also differences between the characters and the styles of the individuals in the generations (Kuyucu, 2017: 847). Therefore, each generation has different preferences, expectations and priorities (Kelgökmen İlic and Yalçın, 2017: 136). However, individuals in the same generation usually have similar attitudes and behaviours (DeVaney, 2015: 11).

The generation- $Y$ is considered to be the ones born between 1980 and 2000, with similar characteristics (Krbová, 2016: 38; Cutler, 2015: 33). In this date range; economic, social, cultural and technological changes took place much faster than other periods (Kuyucu, 2017: 853); however, in comparison to the previous generations, there were no great wars and poverty (Bekmezci, 2017: 105). When compared to previous generations, generation- $Y$ tends to be self-confident, ambitious, caring for the family, appropriate to teamwork, curious, impatient, actively involved in events and express their thoughts clearly (Ayvaz, 2013; Kane, 2017; www.generationy.com; Kuyucu, 2017: 853; Kelgökmen İlic and Yalçın, 2017: 137; Bekmezci, 2017: 105-106). Individuals in this generation are also highly innovative and prefer to use technology and social networks that are the benefits of technology (Djamasbi et al., 2010: 309; Glass, 2007: 99; Kumar and Lim, 2008: 570).

\section{E-WOM}

Word of mouth marketing is when customers talk to each other about a product, service, business, brand and /or marketing activity in their daily lives, without having any kind of marketing purpose. Today, with the development of information technologies and social media, this sharing of information between customers has been moved to the digital platform and a new concept has emerged as electronic word of mouth marketing (e-wom). Customers can perform e-wom activities through forums, complaint sites, social networking sites, blogs, wikis (Ündey Kalpaklığlu, 2015: 71) etc...

In such digital environments, companies can spread information about their products (goods and services), and people who buy that product can share their opinions and experiences with other people. These shares have a significant impact on the purchasing decisions of potential customers (Huang et al., 2011: 1293; Gülmez, 2011: 29; Kitapçı et al., 2012: 266). When it is examined what factors affect people to voluntarily transmit e-wom messages through virtual sites, it is seemed that reputation, dignity, personal satisfaction, self-disclosure to others (Şimşek, 2013: 213), happiness, excitement (Phelps et al., 2004: 344), emotional linkage with advertising (Dobele et al., 2007: 303), entertainment (Baek et al., 2011: 2245), individualism (Ho and Dempsey, 2010: 1000) are some of the important factors.

Customers often try to understand how the service they will buy before buying tourism services, and therefore seek online consumer assessments (Filieri et al., 2015: 175). Online applications and social media, are some of the important source of information about tourism services and facilitate the decision-making process (Litvin et al., 2008: 466; Zainal et al., 2017: 35). Research in the travel and tourism industry has provided evidence that e-wom affects tourism service sales and purchasing intentions (Ye et al., 2009: 182; Arsal et al., 2008: 82; Filieri and McLeay, 2014: 45; Gretzel and Yoo, 2008: 35; Sparks and Browning, 2011: 1310; Vermeulen and Seegers, 2009: 123-124). 


\section{N. Güreş - S. Arslan - C. Yüksel - A. Varışl1 - D. Babat - M. Gündoğdu 11/2 (2019) 905-916}

\section{Trust in E-Wom}

In the tourism industry, quality of service is unknown without experience (Pan and Chiou, 2011: 67). Therefore, customers may face risks and uncertainties related to service (Casaló et al., 2011: 623). In order to eliminate this uncertainty and risk, customers try to obtain information from various sources about the service before taking the purchase action (Zainal et al., 2017: 36). At this point, the reliability of the information comes to the fore. Research has shown that individuals rely more on e-wom created by users who experience the service in question than on their own reviews of the services on their websites (Yoo et al., 2009: 49). But in some cases, customers may distrust these reviews. For example, on some websites, the identities of those who make e-wom are not known ( $\mathrm{Xu}, 2014$ : 136). In some cases, companies or competitors may open fake accounts to make positive / negative comments about services (Filieri et al., 2015: 175). For example, TripAdvisor has been fined by Italy because of publishing comments from people who have not experienced tourism services and not taking the necessary precautions (http://fortuneturkey.com). Therefore, these and similar situations have emerged to trust problems related to e-wom (Yilmazel, 2014: 36). If individuals have a doubt e-wom, they may not from the advantages of e-wom (Pihlaja et al., 2017: 342).

Trust in e-wom can be defined as the value and credibility of comments made on products and determines the acceptance and internalization of these comments by the customers (Algur and Erden, 2015: 88). Research shows that the trust in e-wom for products positively influences the decision and intention of the customers (Park et al., 2011: 74; Gruen et al., 2006: 449; Fan and Miao, 2012: 175). According to another research carried out in the tourism industry by Gretzel et al., (2007: 5), the trust in e-wom has a positive impact on the purchasing intention by reducing the risk that tourists perceive when booking a hotel. Therefore, our first hypothesis is as follows;

$\mathrm{H}_{1}$ : Trust in e-wom has a positive impact on customers' intentions to purchase tourism services.

The Quality of E-wom

Because tourism services are intangible, tourism is based on knowledge. So information provided to current and potential customers is very important. Therefore, especially the information presented in online environments needs to meet the needs and expectations of consumers (No and Kim, 2015: 569). Because this information may reduce the risks perceived by consumers especially in the purchasing decision process (Yilmazel, 2014: 35). Therefore, the information presented in these platforms is expected to be of high quality. According to Park et al. (2007: 128) information quality defined as the quality of the content of a consumer review from the perspective of information characteristics. According to another definition, it refers to a person's strong and consistent perception of the content / assertion of a message (Yoo et al., 2017: 333). The quality of e-wom means that it is relevant and useful for users on online platforms (Awad and Ragowsky, 2008: 103).

If e-wom from online platforms is high quality and users are satisfied with this information, users' motivation to search for information about products may also increase (Hur et al., 2017: 171). When the literature is examined, it was concluded that the trust in knowledge increases the quality of knowledge and that the quality of knowledge has a positive effect on the purchase intentions (Cheung and Thadani, 2012: 468; Awad and Ragowsky, 2008: 101; Park et al., 2007: 125; Tseng and Hsu, 2010: 1). In another study results, if e-wom is perceived as quality, the tourists' desire to book hotels will increase (Sparks and Browning, 2011: 1312). Therefore, our second hypothesis is as follows;

$\mathrm{H}_{2}$ : The quality of e-wom has a positive impact on customers' intentions to purchase tourism services.

\section{Desire to Obtain Information}

In tourism enterprises operating in a service sector, the experience of the service is very important for tourists. Therefore, customers who experience the service may feel the need to share good or bad events with current and potential customers on all platforms. Especially with the development of social media sites, these experiences have been extensively shared and these shares have influenced the customers' intention to buy product (Sarışık and Özbay, 2012: 2; Goldsmith and Horowitz, 2006: 3). From this point, the behaviour of today's customers has changed due to social media (Huang et al., 2017: 757). Now customers are looking for information about hotels, travel companies, restaurants, when they need it (Luo et al., 2011: 22). Social 
N. Güreş - S. Arslan - C. Yüksel - A. Varışlı - D. Babat - M. Gündoğdu 11/2 (2019) 905-916

media sites are also a very useful tool for this purpose (Hur et al., 2017: 172). According to the study of Chung et al. (2015: 902), social media users adopt the travel information of the individuals with whom they communicate on this platform.

Hennig-Thurau and Walsh (2013: 57-58) searched the factors that motivate individuals to obtain information from virtual platforms and identified five factors. These are Information about purchasing, social orientation, belonging to a community, reward and learning how to consume a product. Therefore, today, tourists' desire to obtain information through e-wom has greatly increased (Pihlaja et al., 2017: 340) and the tourism recommendations and experiences such as Tripadvisor and alike platforms have become widespread. As of 2018, there are more than 630 million comments in Tripadvisor including approximately 7.5 million accommodation, airline operation, restaurant and tourism services (https://tripadvisor.mediaroom.com/trabout-use). From this point, the desire to reach e-wom information related to tourism services and reading ewoms, may affect purchasing decision, decision process and purchasing intention of customer (Çakır et al., 2017: 124). Therefore, our third hypothesis is as follows;

$\mathrm{H}_{3}$ : The desire to obtain information has a positive impact on customers' intentions to purchase tourism services.

In addition, the hypotheses to measure the impact of customer demographic characteristics (their gender, education level, outcome, daily social media usage of customers) on tourism service purchase are as follows;

$\mathrm{H}_{4 a}$ : Customers' intentions to purchase tourism services has a significant difference according to their gender.

$\mathrm{H}_{4 \mathrm{~b}}$ : Customers' intentions to purchase tourism services has a significant difference according to their age.

$\mathrm{H}_{4 c:}$ Customers' intentions to purchase tourism services has a significant difference according to their education level.

$\mathrm{H}_{4 \mathrm{~d}}$ : Customers' intentions to purchase tourism services has a significant difference according to their income.

$\mathrm{H}_{4 \mathrm{e}}$ : Customers' intentions to purchase tourism services has a significant difference according to daily social media usage of customers.

In line with the hypotheses, the model of the study is as follows.

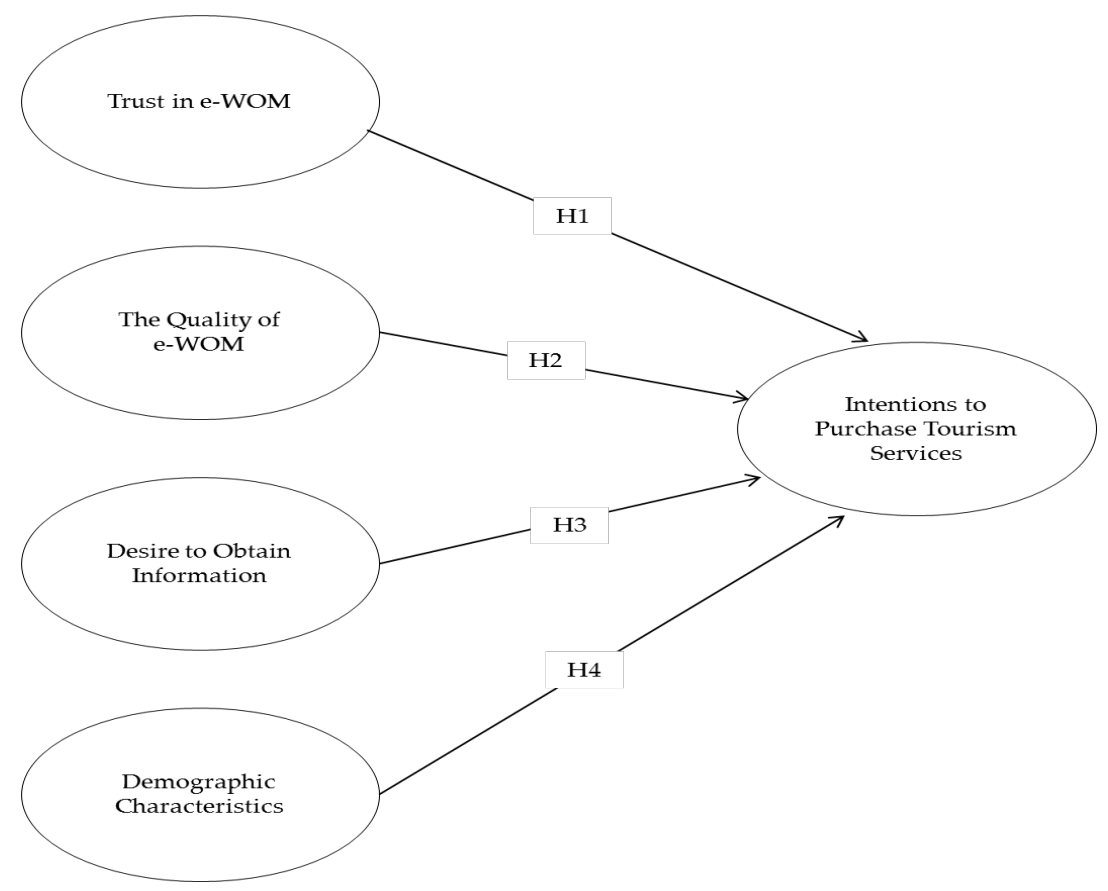

Figure 1. Model of the Research 
N. Güreş - S. Arslan - C. Yüksel - A. Varışl1 - D. Babat - M. Gündoğdu 11/2 (2019) 905-916

\section{Methodology}

\section{Measures of the Constructs}

In this study, reason-result research was used. The reason-result study is carried out to ascertain whether there really is such a relationship between one or more independent variables that are thought to be related to each other. (Karafakığlu, 2005: 70). Question forms were created using the questionnaire method which is one of the quantitative methods. In this context, the questionnaire was formed and consisted of two parts. The first part includes questions about e-wom and the intention to buy and the second part includes demographic questions about the respondents.

For the creation of the questions in the first part, Özcan and Akıncı (2017: 147) and Hur et al. (2017: 176177)'s studies were utilized and questions were prepared in the form of a likert scale as; 1 (I definitely disagree) ...... and 5 (certainly agree). Demographic questions include gender, age, monthly average income, educational level, how long and how often social media tools are used, which tourism services are purchased by being affected by e-wom.

\section{Data Collection and Sample Design}

The universe of the research is composed of individuals born in Turkey between 1980 and 2000 and in Y Generation. According to data from Turkish Statistical Institute (www.tuik.gov.tr) in 2018, a total of 27.926.575 people are involved in Y-Generation. However, due to the excess number of the universe, lack of sampling frames and time constraints, an easy sampling method was used which is one of the non-random sampling methods. The number of samples was found to be 384 for the sample group in the calculation with a 5\% error margin in the 95\% confidence interval (http://www.macorr.com). 485 forms were applied face to face and internet in consideration of the possibility of missing and incorrect filling of the questionnaires. But 416 questionnaires were analysed after excluding invalid questionnaires.

\section{Data Analysis}

In this study, frequency distributions and mean (mean) values are given as one of descriptive statistical analyses. In addition, T-test and One-Way ANOVA analyses were used to test whether demographic variables have an impact on the intention to purchase tourism services. While T-test is used to test whether the difference between the two unbound sampling averages is significant (Büyüköztürk, 2010: 39-40); OneWay ANOVA is used to test whether the main mass of the population is equal or not, and whether there are differences between the variables (Büyüköztürk, 2010: 48). The regression analysis was used to describe the relationship between the independent variables trust in e-wom, the quality of e-wom, desire to obtain information, dependent variables, intentions to purchase tourism services. Regression analysis is the process of explaining the relationship between two or more variables, one dependent variable, and the other independent variable, with mathematical equality (Büyüköztürk, 2010: 91).

Reliability measures the consistency between individual responses to the questionnaire, in other words, shows how accurately the questionnaire measures the information desired to be measured. (Büyüköztürk, 2010: 169-170). Accordingly, when cronbach a assessments which represent the security layers for the changes in survey reviews examined, $\alpha=0.71$ for trust in e-wom, $\alpha=0.81$ for the quality of e-wom, $\alpha=0.86$ to obtain the desire for information, and $\alpha=0.72$ for diffusion management as a practise to purchase tourism services have been identified. From this point of view, it is observed that the questions and the answers to the questions are consistent $(a>0.70)$.

\section{Results}

Demographic information of the customers involved in the survey is as shown on Table 1 . According to the results, 136 (33\%) of the participants were female, 280 (67\%) were male, and the majority were in the $20-29$ age range. Most of the participants have a bachelor's degree (66\%) and the average monthly income of majority is between 1600 and $2600 \mathrm{TL}$ (28\%). 20\% of the participants used the social media less than 1 hour per day, $63 \%$ used $2-6$ hours per day, $11 \%$ used $7-11$ hours per day and $6 \%$ used it for 12 hours per day. Customers in the Y Generation were asked which social media tools they used when deciding to purchase tourism services. According to the answers, 280 people use social media tools such as Instagram, 188 people YouTube, 154 people Facebook, 103 people Blog, 101 people Twitter, 68 people TripAdvisor and 61 people 
N. Güreş - S. Arslan - C. Yüksel - A. Varışl1 - D. Babat - M. Gündoğdu 11/2 (2019) 905-916

social marking and labelling. Finally, the participants use social media mostly for travel (244 people), for accommodation (196 people) and for food and beverage (189 people).

Table 1. Demographic Characteristics

\begin{tabular}{|c|c|c|c|}
\hline & & $\mathbf{N}$ & $\%$ \\
\hline \multirow{2}{*}{ Gender } & Female & 136 & 33.00 \\
\hline & Male & 280 & 67.00 \\
\hline \multirow{3}{*}{ Age } & Under 20 age & 56 & 14.00 \\
\hline & $20-29$ age & 354 & 85.00 \\
\hline & $30-39$ age & 6 & 1.00 \\
\hline \multirow{5}{*}{ Education Level } & Primary education & 1 & 1.00 \\
\hline & High school & 35 & 8.00 \\
\hline & Associate degree & 101 & 24.00 \\
\hline & Bachelor degree & 278 & 66.00 \\
\hline & Post graduate & 1 & 1.00 \\
\hline \multirow{5}{*}{ Average income } & Under $1600 \mathrm{TL}$ & 73 & 17.00 \\
\hline & $1600-2600 \mathrm{TL}$ & 115 & 28.00 \\
\hline & $2601-3600 \mathrm{TL}$ & 96 & 23.00 \\
\hline & $3601-4600 \mathrm{TL}$ & 70 & 17.00 \\
\hline & 4601 TL and above & 62 & 15.00 \\
\hline \multirow{7}{*}{$\begin{array}{l}\text { Social media tools used when buying } \\
\text { tourism services (exceeds } 100 \% \\
\text { because they can be marked more than } \\
\text { one) }\end{array}$} & Facebook & 154 & 37.00 \\
\hline & Twitter & 101 & 24.00 \\
\hline & Instagram & 280 & 67.00 \\
\hline & Blog & 103 & 25.00 \\
\hline & Youtube & 188 & 45.00 \\
\hline & TripAdvisor & 68 & 16.00 \\
\hline & Social marking and labelling & 61 & 15.00 \\
\hline \multirow{4}{*}{ Daily social media usage time } & Less than 1 hour & 84 & 20.00 \\
\hline & $2-6$ hours & 263 & 63.00 \\
\hline & $7-11$ hours & 44 & 11.00 \\
\hline & 12 hours or more & 25 & 6.00 \\
\hline \multirow{5}{*}{$\begin{array}{l}\text { Social media tools used while } \\
\text { purchasing tourism services (exceeds } \\
100 \% \text { because it can be marked more } \\
\text { than one) }\end{array}$} & Accomodation & 196 & 47.00 \\
\hline & Travel & 244 & 59.00 \\
\hline & Food and Beverage & 189 & 45.00 \\
\hline & Travel Agency & 123 & 30.00 \\
\hline & Other & 90 & 22.00 \\
\hline
\end{tabular}

According to the proposed research model, regression analysis was made to measure the impact of trust in E-Wom on customers' intention to buy tourism services and the results were presented in Table 2.

Tablo 2. Regression results about trust in e-wom * customers' purchase intention

\begin{tabular}{|l|c|r|c|}
\hline Model & Standardized Coefficient $(\beta)$ & t-value & $\mathrm{p}$ \\
\hline $\begin{array}{l}\text { Dependent Variable: Intention to } \\
\text { purchase }\end{array}$ & & & \\
\hline Constant & - & 14.039 & .000 \\
\hline Trust in e-wom & 0.371 & 8.128 & .000 \\
\hline
\end{tabular}

With respect to the results of the regression analysis, it was determined that there was a significant relationship between the trust in e-wom and the customers' intention to buy tourism services. So, H1 hypothesis is supported. According to the analysis, trust in e-wom is a significant indicator of the customers' intention to buy tourism services $[\mathrm{R}=0.371, \mathrm{R} 2=0.138, \mathrm{~F}(1,414)]=66.071, \mathrm{p}<0.05]$. It was concluded that 14 $\%$ of the total variance for customers ' intention to purchase tourism services was explained with trust in ewom. 
N. Güreş - S. Arslan - C. Yüksel - A. Varışlı - D. Babat - M. Gündoğdu 11/2 (2019) 905-916

In order to measure the impact of e-wom quality on customers ' intention to buy tourism services, regression analysis was made and the results were presented in Table 3.

Tablo 3. Regression results about the quality of e-wom * customers' purchase intention

\begin{tabular}{|l|c|c|c|}
\hline Model & Standardized Coefficient $(\beta)$ & $\mathrm{t}$-value & $\mathrm{p}$ \\
\hline $\begin{array}{l}\text { Dependent Variable: Intention to } \\
\text { purchase }\end{array}$ & & & \\
\hline Constant & - & 12.293 & .000 \\
\hline The quality of e-wom & 0.475 & 10.996 & .000 \\
\hline
\end{tabular}

According to the results, it was determined that there was a significant relationship between e-wom's quality and customers ' intention to buy tourism services. $\mathrm{H} 2$ hypothesis is therefore supported. According to the analysis, e-wom quality is a significant indicator of customers ' intention to purchase tourism services $[\mathrm{R}=$ $0.475, \mathrm{R} 2=0.226, \mathrm{~F}(1,414)=120.918, \mathrm{p}<0.05]$. It was concluded that $23 \%$ of the total variance for customers ' intention to purchase tourism services was explained by e-wom quality.

In order to measure the impact of customers' desire to obtain information from social media on customers' intention to buy tourism services, a regression analysis was made and the results of the analyses were presented in Table 4.

Tablo 4. Regression results about desire to obtain information * customers' purchase intention

\begin{tabular}{|l|c|r|c|}
\hline Model & Standardized Coefficient $(\beta)$ & $\mathrm{t}$-value & $\mathrm{p}$ \\
\hline $\begin{array}{l}\text { Dependent Variable: Intention to } \\
\text { purchase }\end{array}$ & & & \\
\hline Constant & - & 14.386 & .000 \\
\hline Desire to obtain information & 0.424 & 9.525 & .000 \\
\hline $\mathrm{R}^{2}=0.180 ;$ F-value = 90.721; $\mathrm{df}=1,414 ;$ Adjusted $\mathrm{R}^{2}=0.178$; Significance $=0.000$ \\
\hline
\end{tabular}

Analysis result showed that there was a significant relationship between the desire of customers to obtain information from the social media and the intention to buy tourism services. Therefore, H3 hypothesis is supported. The desire to obtain information is a significant indicator of the intention of the customers to buy tourism services $[R=0.424, R 2=0.180, F(1,414)=90.721, p<0.05] .18 \%$ of the total variance for customers' intention to purchase tourism services was explained by the desire to obtain information from the social media.

Whether there was a significant relationship between the daily use of social media tools and the intention to purchase tourism services was analyzed with ANOVA (Group 1 : Less than 1 hour Group 2: $2-6$ hour Group 3: 7 - 11 hour Group 4: 12 hours and more). According to ANOVA results, customers' intentions to purchase tourism services has a significant difference according to daily social media usage of customers $[\mathrm{F}(3,411)=6.288, \mathrm{p}<0.05]$. H4e is supported (Table 5). Respondents' intention to purchase tourism services varies according to the frequency of social media use. According to Scheffe test results, as the frequency of use of social media increases, responders ' intention to purchase tourism services increases (average for those using more than 12 hours per day $=3.57$, average for those using less than 1 hour). $=2.96$ ).

Table 5. ANOVA results of customers' purchase intentions according to daily social media usage

\begin{tabular}{|c|c|c|c|c|c|c|}
\hline & Sum of Squares & $\mathrm{df}$ & Mean Square & $\mathrm{F}$ & sig. & $\begin{array}{l}\text { Significant } \\
\text { difference }\end{array}$ \\
\hline $\begin{array}{l}\text { Between } \\
\text { Groups }\end{array}$ & 13.756 & 3 & 4.585 & \multirow[t]{3}{*}{6.288} & \multirow[t]{3}{*}{.000} & \multirow{3}{*}{$\begin{array}{l}\text { 1.group - 3.group } \\
\text { 2.group-3.group }\end{array}$} \\
\hline $\begin{array}{l}\text { Within } \\
\text { Groups }\end{array}$ & 299.698 & 411 & \multirow[t]{2}{*}{.729} & & & \\
\hline Total & 313.454 & 414 & & & & \\
\hline
\end{tabular}

Whether there was a significant relationship between the gender of the participants and the intention to purchase tourism services was analysed with T-Test. However, there was no significant relationship between the variables. H4a is therefore not supported. Whether there was a significant relationship between 
N. Güreş - S. Arslan - C. Yüksel - A. Varışlı - D. Babat - M. Gündoğdu 11/2 (2019) 905-916

the intention to purchase tourism services and the age, educational level and monthly average income of the customers in generation $\mathrm{Y}$ were analysed with the Oneway ANOVA. However, there was no significant relationship between the variables. Therefore, $\mathrm{H} 4 \mathrm{~b}, \mathrm{H} 4 \mathrm{c}, \mathrm{H} 4 \mathrm{~d}$ hypotheses are not supported.

The trust in e-wom, the quality of e-wom, the desire of customers to obtain information from the social media and the intention to purchase tourism services, were examined by means of factor-based descriptive statistics and the results are presented in Table 6.

Table 6. Means of Measures

\begin{tabular}{|l|c|c|c|r|}
\hline & Minimum & Maksimum & Mean & \multicolumn{1}{|c|}{ Std. Deviation } \\
\hline Trust in e-wom & 1 & 5 & 3.0958 & .84214 \\
\hline The quality of e-wom & 1 & 5 & 2.8925 & .77993 \\
\hline Desire to obtain information & 1 & 5 & 3.5882 & 1.02796 \\
\hline Intention to purchase & 1 & 5 & 3.3073 & .86927 \\
\hline
\end{tabular}

When the average responses to the variables that constitute the model of the study were examined; trust in e-wom (3.10), quality of e-wom (2.89) and the intention to buy tourism services (3.31) were gathered around the value of " 3 ", which corresponded to the phrase "Neutral". As a result of the research, it was determined that the average of customers' requests for information was 3.59, which corresponds to the expression "I agree".

\section{Conclusion and Recommendations}

With regard to the study results, $67 \%$ of the participants are male (280), $85 \%$ are young (20 - 29 age), $66 \%$ have high education level (university) and $51 \%$ have average monthly income (1600-3600 TL). Many of the participants used the social media 2-6 hours per day (63\%). In addition, customers in the Y generation (280 people) use social media tools such as Instagram, YouTube (188 people), Facebook (154 people) used when deciding to purchase tourism services. Finally, the participants use social media mostly for travel (244 people), for accommodation (196 people) and for food and beverage (189 people).

Morever, the trust in e-wom (this result is consistent with Gruen et al., 2006: 449; Fan and Miao, 2012: 175; Gretzel et al., 2007: 5), quality of e-wom (this result is consistent with Cheung and Thadani, 2012: 468; Awad and Ragowsky, 2008: 101; Park et al., 2007: 125; Tseng and Hsu, 2010: 1; Sparks and Browning, 2011: 1310) and the desire of customers to obtain information have a significant and positive impact on purchase intention to buy tourism services.

Companies should obtain information through e-wom regularly, share feedback from negative e-wom with their employees and make necessary improvements. Thus customers' comments through e-wom for tourism services may change positively. Qualified personnel should be hired to concern about e-wom continuously. If there is a problem, the solution should be produced quickly. In this way, information through e-wom related to tourism services may be more affirmative and the perception of customers towards the quality of tourism services may be increased in a favourable way.

Users try to obtain reliable, convincing information about tourism services from different sources. During the acquisition of information, they interact with each other on the internet platforms. Especially with positive experiences, e-wom may increase the purchasing possibilities of services. Companies should provide true information about their services, photographs, the price, guaranteed service, and resolve complaints in an effective way. Thus, e-wom may increase resource reliability and increase the request for information.

Tourism service is a process including many activities. All activities taking place in this process are very important for tourism enterprises and should take place without any disruption. Therefore, the quality of information related to tourism services in this process may affect the customers' perceptions about overall quality of service. In addition, the quality of e-wom may enhance the motivation and desire of customers to search information through Internet / social media sites. Because customers are looking for quality, understandable and accurate information while utilizing e-wom from internet / social media sites. Companies that deal with e-wom (especially negative e-wom) should respond in time and positively to users 
N. Güreş - S. Arslan - C. Yüksel - A. Varışlı - D. Babat - M. Gündoğdu 11/2 (2019) 905-916

who comment on different issues using different expressions. By this way, the quality of e-wom may be increased.

The participants' desire to search for information before buying tourism services are relatively high. However, since the quality of e-wom and the average of trust in e-wom are relatively low, customers' desire for information may also be negatively affected. This situation may lead to customers' intention as not buying tourism services. Therefore, companies should carefully address the comments expressed through ewom (especially negative aspects), respond positively and make improvements in their services. This may positively affect the customers' intentions to purchase tourism services by considering e-wom.

As a result in this study, the confidence in e-wom, the quality of e-wom and desire to obtain information variables were found to be relatively low in terms of explaining the customers ' intention to purchase tourism services. Therefore, different variables such as image, price, physical elements, competition and quality may be searched to see the effect on the intention of buying tourism services. For this reason, in future studies, taking these variables into consideration may be beneficial in terms of contributing to both literature and airline operations.

\section{References}

Alfina, I., Ero, J., Hidayanto, A. N. and Shihab, M. R. (2014). The impact of cognitive trust and e-wom on purchase intention in C2C e-commerce site, Journal of Computer Science, 10 (12), 2518-2524.

Algur, M. S. and Erden, N.S. (2015). The mediating role of trust towards e-wom on the relationship between big five personality characteristics and influence by e-wom, İ. Ü. İşletme Fakültesi İşletme İktisadı Enstitüsü Yönetim Dergisi, 26 (78), 87-99.

Amaro, S., Duarte, P. and Henriques, C. (2016). Travelers' use of social media: A clustering approach, Annals of Tourism Research, 59, 1-15.

Arsal, I., Backman, S. and Baldwin, E. (2008). Influence of an online travel community on travel decisions, in Information and Communication Technologies in Tourism, in Vienna, Austria, 2008, Springer-Verlag, 82-93.

Awad, N. F. and Ragowsky, A. (2008). Establishing trust in electronic commerce through online word of mouth: An examination across genders, Journal of Management Information Systems, 4 (4), 101-21.

Ayvaz, T. (2013), Y kuşağı özellikleri, www.dijitalajanslar.com/y-kusagi/ (Erişim tarihi: 15.02.2018)

Baek, K., Holton, A., Harp, D. and Yaschur, C. (2011). The links that bind: Uncovering novel motivations for linking on Facebook, Computers in Human Behavior, 27 (6), 2243-2248.

Bekmezci, M. (2017). Kuşakların karşılaştırılması ve e-iş dünyasında ' $Y$ ' kuşağına kuramsal bir bakış, Toros Üniversitesi İSBF Sosyal Bilimler Dergisi, 4 (7), 101-111.

Bhatiasevi, V. and Yoopetch, C. (2015). The determinants of intention to use electronic booking among young users in Thailand, Journal of Hospitality and Tourism Management, 23, 1-11.

Bilgihan, A., Barreda, A., Okumus, F. and Nusair, K. (2016). Consumer perception of knowledge-sharing in travel-related online social networks, Tourism Management, 52, 287-296.

Büyüköztürk, Ş. (2010). Sosyal Bilimler İçin Veri Analizi El Kitabı, Ankara: Pegem Akademi.

Caragliu, A., Del Bo, C. D. and Nijkamp, P. (2011). Smart cities in Europe, Journal of Urban Technology, 18 (2), 65-82.

Casaló, L. V., Flavian, C. and Guinalíu, M. (2011). Understanding the intention to follow the advice obtained in an online travel community, Computers in Human Behavior, 27 (2), 622-633.

Cheung, C.M.K and Thadani, D.R. (2012). The impact of electronic word-of-mouth communication: A literature analysis and integrative model, Decision Support Systems, 54 (1), 461-470.

Chung, J. Y. and Buhalis, D. (2008). Web 2.0: A study of online travel community, in Information and Communication Technologies in Tourism, in Vienna, Austria, 2008, Springer-Verlag, 70-81. 
N. Güreş - S. Arslan - C. Yüksel - A. Varışl1 - D. Babat - M. Gündoğdu 11/2 (2019) 905-916

Chung, N., Han, H. and Koo, C. (2015). Adoption of travel information in user generated content on social media: The moderating effect of social presence, Behavior and Information Technology, 34 (9), 902-919.

Cutler, N. E. (2015). Millennials and finance: The "Amazon Generation", Journal of Financial Service Professionals, 69 (6), 33-39.

Çakır, F., Aybar, N. and Akel, G. (2017). E-wom'un tüketicilerin tatil satın alma niyetine etkisi, Adnan Menderes Üniversitesi Sosyal Bilimler Enstitüsü Dergisi, 4 (4), 110-127.

DeVaney, S. A. (2015). Understanding the millennial generation, Journal of Financial Service Professionals, 69 (6), 11-14.

Djamasbi, S., Siegel, M. and Tullis, T. (2010). Generation Y, web design, and eye tracking, International Journal of Human-Computer Studies, 68 (5), 307-323.

Dobele, A., Lindgreen, A., Beverland, M., Vanhamme, J. and Van Wijk, R. (2007). Why pass on viral messages? Because they connect emotionally, Business Horizons, 50 (4), 291-304.

Fan, Y.W. and Miao, Y. F. (2012). Effect of electronic word-of-mouth on consumer purchase intention: The perspective of gender differences, International Journal of Electronic Business Management, 10 (3), 175181.

Filieri, R. and McLeay, F. (2014). E-wom and accommodation: An analysis of the factors that influence travelers' adoption of information from online reviews, Journal of Travel Research, 53 (1), 44-57.

Filieri, R., Alguezaui, S. and McLeay, F. (2015). Why do travelers trust TripAdvisor? Antecedents of trust towards consumer-generated media and its influence on recommendation adoption and word of mouth, Tourism Management, 51, 174-185.

Foroudi, P., Gupta, S., Sivarajah, U. and Broderick, A. (2018). Investigating the effects of smart technology on customer dynamics and customer experience, Computers in Human Behavior, 80, 271-282.

Fotis, J., Buhalis, D. and Rossides, N. (2012). Social media use and impact during the holiday travel planning process, in Information and Communication Technologies in Tourism, in Vienna, Austria, 2012, SpringerVerlag, 13-24.

Glass, A. (2007). Understanding generational differences for competitive success, Industrial and Commercial Training, 39 (2), 98-103.

Goldsmith, R. E. and Horowitz, D. (2006). Measuring motivations for online opinion seeking, Journal of Interactive Advertising, 6 (2), 2-14.

Gretzel, U., Yoo, K. H. and Purifoy, M. (2007), Online travel review study: Role and impact of online travel reviews. Austin, TX: Laboratory for Intelligent Systems in Tourism, Texas A\&M University, https://www.tripadvisor.com/pdfs/OnlineTravelReviewReport.pdf (Erişim tarihi: 15.02.2018).

Gretzel, U. and Yoo, K. H. (2008). Use and impact of online travel reviews, in Information and Communication Technologies in Tourism, in Vienna, Austria, 2008, Springer-Verlag, 35-46.

Gretzel, U. (2011). Intelligent systems in tourism: A social science perspective, Annals of Tourism Research, Vol: 38, Issue: $3,757-779$.

Gruen, T. W., Osmanbekov, T. and Czaplewski, A.J. (2006). E-wom: The impact of customer-to-customer online know-how e-exchange on customer value and loyalty, Journal of Business Research, 59, 449-45.

Gülmez, M. (2011). İnternet üzerinde ağızdan ağıza pazarlama uygulama örnekleri, İnternet Uygulamaları ve Yönetimi, 2 (1), 29-36.

Hennig-Thurau, T. and Walsh, G. (2003). Electronic word-of-mouth: Motives for and consequences of reading customer articulations on the internet, International Journal of Electronic Commerce, 8 (2), 51-74.

Ho, J. Y. and Dempsey, M. (2010). Viral marketing: Motivations to forward online content, Journal of Business Research, 63 (9), 1000-1006. 
N. Güreş - S. Arslan - C. Yüksel - A. Varışl1 - D. Babat - M. Gündoğdu 11/2 (2019) 905-916

Huang, M., Cai, F. and Tsang, A.S.L. (2011). Making your online voice loud: The critical role of wom information, European Journal of Marketing, 45 (7/8), 1277-1297.

Huang, C. D., Goo, J., Nam, K. and Yoo, C.W. (2017). Smart tourism technologies in travel planning: The role of exploration and exploitation, Information \& Management, 54, 757-770.

Hur, K., Kim, T. T., Karatepe, O. M. and Lee, G. (2017). An exploration of the factors influencing social media continuance usage and information sharing intentions among Korean travellers, Tourism Management, $63,170-178$.

http://www.generationy.com (Erişim tarihi: 15.02.2018).

Karafakığlu, M. (2005). Pazarlama Illkeleri, Literatür Yayınları: İstanbul.

Kane, S. (2017), Common characteristics of generation Y professionals: What employers should know about their Gen Y employees, https://www.thebalance.com/common-characteristics-of-generation-yprofessionals-2164683 (Erişim tarihi: 15.02.2018).

Kelgökmen İlic, D. and Yalçın, B. (2017). Y jenerasyonunun farklılaşan iş değerleri ve liderlik algılamaları, Journal of Yasar University, 12 (46), 136-160.

Kitapçı, O., Taştan, S., Dörtyol, İ. T. and Akdoğan, C. (2012). Ağızdan ağıza çevrimiçi iletişimin otellerdeki oda satışlarına etkisi üzerine bir araştırma, Doğuş Üniversitesi Dergisi, 13 (2), 266- 274.

Krbová, P. K. (2016). Generation Y attitudes towards shopping: A comparison of the Czech Republic and Slovakia, Journal of Competitiveness, 8 (1), 38-54.

Kumar, A. and Lim, H. (2008). Age differences in mobile service perceptions: Comparison of generation Y and baby boomers, Journal of Services Marketing, 22 (7), 568-577.

Kuyucu, M. (2017). Y kuşağı ve teknoloji: Y kuşağının iletişim teknolojilerini kullanım alışkanlıkları, Gümüşhane Üniversitesi İletişim Fakültesi Elektronik Dergisi, 5 (2), 845 - 872.

Litvin, S. W., Goldsmith, R. E. and Pan, B. (2008). Electronic word-of-mouth in hospitality and tourism management, Tourism Management, 29 (3), 458-468.

Luo, M. M., Chea, S. and Chen, J. (2011). Web-based information service adoption: A comparison of the motivational model and the use and gratifications theory, Decision Support Systems, 51 (1), 21-30.

http://www.macorr.com/sample-size-calculator.htm (Erişim Tarihi: 07.01.2018)

No, E. and Kim, J.K. (2015). Comparing the attributes of online tourism information sources, Computers in Human Behavior, 50, 564-575.

Özcan, B. and Akıncı, Z. (2017). Sosyal medyanın üniversite öğrencilerinin tüketici davranışları üzerinde etkisi: Turizm fakültesi örneği, Süleyman Demirel Üniversitesi Vizyoner Dergisi, 8 (18), 141-154.

Pan, L.-Y. and Chiou, J.-S. (2011). How much can you trust online information? Cues for perceived trustworthiness of consumer-generated online information, Journal of Interactive Marketing, 25 (2), 6774.

Park, D.-H., Lee, J. and Han, I. (2007). The effect of online consumer reviews on consumer purchasing intention: The moderating role of involvement, International Journal of Electronic Commerce, 11 (4), 125148.

Park, C., Wang, Y., Yao, Y. and Kang, Y.R. (2011). Factors influencing e-wom effects: Using experience, credibility, and susceptibility, International Journal of Social Science and Humanity, 1 (1), 74-79.

Phelps, J.E., Lewis, R., Mobilio, L., Perry, D. and Raman, N. (2004). Viral marketing or electronic word-ofmouth advertising: Examining consumer responses and motivations to pass along email, Journal of Advertising Research, 44 (4), 333-348.

Pihlaja, J., Saarijärvi, H., Spence, M. T. and Yrjölä, M. (2017). From electronic wom to social e-wom: Bridging the trust deficit, Journal of Marketing Theory and Practice, 25 (4), 340-356. 
N. Güreş - S. Arslan - C. Yüksel - A. Varışlı - D. Babat - M. Gündoğdu 11/2 (2019) 905-916

Sarışık, M. and Özbay, G. (2012). Elektronik ağızdan ağıza iletişim (e-wom) ve turizm endüstrisindeki uygulamalara ilişkin bir yazın incelemesi, Uluslararası Yönetim İktisat ve İşletme Dergisi, 8 (16), 1-22.

Sparks, B. A. and Browning, V. (2011). The impact of online reviews on hotel booking intentions and perception of trust, Tourism Management, 32 (6), 1310-1323.

Şimşek, G. (2013). Kişisel mecralarda reklam yayını: Kişilerin sosyal medyada reklam paylaşım motivasyonları, Akademik Incelemeler Dergisi, 8 (3), 213-239.

TripAdvisor Hakkında, https://tripadvisor.mediaroom.com/tr-about-us (Erişim tarihi: 15.02.2018)

Tseng, F.M., Hsu, F.Y. (2010). The influence of e-wom within the online community on consumers' purchasing intentions - The case of the Eee PC, in The 2010 International Conference on Innovation and Management, Penang, Malaysia.

Türkiye İstatistik Kurumu, 2019, www.tuik.gov.tr (Erişim tarihi: 07.01.2018)

Ündey Kalpaklığlu, N. (2015). Bir pazarlama iletişimi unsuru olarak e-wom'un turizm ürünleri tercihine etkisi, Maltepe Üniversitesi İletişim Fakültesi Dergisi, 2 (1), 66-90.

Vermeulen, I. E. and Seegers, D. (2009). Tried and tested: The impact of online hotel reviews on consumer consideration, Tourism Management, 30 (1), 123-127.

Wang, X., Li, X.R., Zhen, F. and Zhang, J.H. (2016). How smart is your tourist attraction?: Measuring tourist preferences of smart tourism attractions via a FCEM-AHP and IPA approach, Tourism Management, 54 (June), 309-320.

Xu, Q. (2014). Should I trust him? The effects of reviewer profile characteristics on e-wom credibility, Computers in Human Behavior, 33, 136-144.

Ye, Q., Law, R. and Gu, B. (2009). The impact of online user reviews on hotel room sales, International Journal of Hospitality Management, 28 (1), 180-182.

Ye, B. H., Zhang, H. Q., Shen, J. H. and Goh, C. (2014). Does social identity affect residents' attitude toward tourism development?: An evidence from the relaxation of the individual visit scheme, International Journal of Contemporary Hospitality Management, 26 (6), 907-929.

Yılmazel, S. E. (2014). Web site kalitesi ile elektronik kulaktan kulağa iletişim tutumu ve marka tutumu arasındaki ilişkide elektronik kulaktan kulağa iletişim kalitesi ve kredibilitesinin etkisi. Hacettepe Üniversitesi Sosyal Bilimler Enstitüsü İşletme Anabilim Dalı. Pazarlama Bilim Dalı, Yüksek Lisans Tezi, Ankara.

Yoo KH., Lee Y., Gretzel U. and Fesenmaier D.R. (2009). Trust in travel-related consumer generated media, in Information and Communication Technologies in Tourism, in Vienna, Austria, 2009, Springer-Verlag.

Yoo, C. W., Goo, J., Huang, C.D., Nam, K. and Woo, M. (2017). Improving travel decision support satisfaction with smart tourism technologies: A framework of tourist elaboration likelihood and selfefficacy, Technological Forecasting \& Social Change, 123, 330-341.

Zainal, N. T. A., Harun, A. and Lily, J. (2017). Examining the mediating effect of attitude towards electronic words-of mouth (eWOM) on the relation between the trust in eWOM source and intention to follow eWOM among Malaysian travellers, Asia Pacific Management Review, 22, 35-44. 